\title{
Transformational Leadership Model \& Marketing Supporting the Rall of Auditor According to Job Ethics and International Accounting Standard
}

\author{
Atared Saad Jebur AL-Mashhadia ${ }^{\text {a }}$ Muiead A.K. Al-Fadhel ${ }^{\text {b }}$ \\ ${ }^{a}$ Al-Mustaqbal University College, Accounting Department, Iraq. \\ ${ }^{\mathrm{b}}$ Al-Mustaqbal University College, Department of Business Management, Iraq.
}

Article History: Received: 11 January 2021; Accepted: 27 February 2021; Published online: 5 April 2021

\begin{abstract}
The research includes (an exploratory study of economic units in Iraq after the year 2003). The aims of our study can be clarified through the following questions: First: Does the exercise of the supervisory role in the economic unit require an important and essential role for the auditor based on the transformational leadership and self-marketing component. Second: Exercising the supervisory role in the economic unit requires adopting the arts of self-marketing for the accounts auditor to convey the content of his ideas and his method of work. Third: Does the application of international standards require the auditor's involvement in a transformative leadership role, in order to reduce tensions and differences of opinion regarding the application of the mentioned standards. Fourth: Do workers in the various departments of the economic unit and mainly in the accounting departments need to be directed and led towards the new reality of applying international standards, or not.
\end{abstract}

Keywords: Economic, Self-marketing, Standards, Leadership.

\section{Introduction}

The economic and administrative system of any country is based on the element of control, scrutiny and followup of the process of spending and exploitation of material resources that are used to support and develop economic units. He plays both:

1. Office of Financial Supervision / for government units.

2. Accounts organizing offices / for private sector units.

An important role in the process of monitoring, auditing, and following-up on all money spending operations and recognizing them, as both cases rely on the auditor as he is authorized to act to implement the will of the state or the general right. Hence the auditor's role as the leader who leads a team of auditors to begin carrying out the task. Researchers believe that the auditor is based on:

1. Professional ethics

2. International accounting standards

It stands before a set of options in choosing the leadership style (authoritarian leadership, position leadership, inclusive leadership, transformational leadership,... etc.) in order to lead the work team responsible for the audit and control process.

The researchers go with the hypothesis of adopting transformational leadership that relies on transforming the algorithm from a certain reality into a better reality, where this role of leadership is exercised for each of:

First: The work team coming from outside the economic unit.

Second: Workers in the accounting and administrative system in the same economic unit.

In order to practice this type of leadership, it is necessary to strengthen this leadership role, by relying on selfmarketing, meaning that an auditor who wishes to exercise the role of transformational leadership must market himself well according to two types of specifications:

1. Formal specifications

2. Quality specifications

The formal specifications are intended to have an observer. Accounts are characteristics related to the general form in terms of (tallness, serious stature at work, mastery of body language, and so on). As for the qualitative specifications, they are intended, as the accounts auditor possesses scientific and academic qualifications that are considered for him the knowledge basis in addressing the various problems in the practical reality of the different 
economic units. Our study falls into four parts, the first is devoted to the practical aspect, and finally the conclusions and recommendations are in the fourth part, and then came the Arab and foreign sources.

\section{The First Part: Scientific Methodology and Previous Studies}

\section{Scientific Methodology of the Study}

Study problem: The problem of our study can be clarified through the following questions:

First: Does the exercise of the supervisory role in the economic unit require an important and essential role for the auditor based on the transformational leadership and self-marketing component?

Second: Exercising the supervisory role in the economic unit requires adopting the arts of self-marketing for the accounts auditor to convey the content of his ideas and his method of work.

Third: Does the application of international standards require the auditor's involvement in a transformative leadership role, in order to reduce tensions and differences of opinion regarding the application of the mentioned standards?

Fourth: Do workers in the various departments of the economic unit and mainly in the accounting departments need to be directed and led towards the new reality of applying international standards?

Study Hypotheses: Our study is based on the following hypotheses:

1. Suppose that the application of control measures in the economic unit requires an important and essential role for the auditor based on the ethics of the profession and international standards.

2. Suppose that the arts of self-marketing is adopted by the auditor in order to convey the idea and feasibility of the transformation towards developing the current reality.

3. Assume that there is a statistically significant relationship between the role of transformational leadership and self-marketing of the auditor and the possibility of raising the level of accounting reality and thus the development of the general accounting and administrative system in the economic unit.

4. Assume that there is a statistically significant relationship between the employees 'understanding of the importance of the transformational leadership role and the arts of self-marketing for the auditor and the development of the accounting and management system in the economic unit.

Study Objectives: Our study aims to achieve the following:

First: Explaining the importance of the transformational leadership role of the auditor (internal and external) in the transition towards international standards (IFRIS).

Second: Explaining the importance of self-marketing arts for the auditor in reaching the stage of conviction and satisfaction of the employees with the accounts of the auditor's proposals in transforming into an advanced accounting and management level based on acceptance of his personality and not being alienated from him

Third: Transformation Creating an intellectual and practical basis in economic unity by convincing workers and decision-makers of the need to shift towards globalization and keep pace with global developments by creating his conviction according to international standards.

The Importance of The Study: The importance of our study stems from the following points:

1. Shedding light on the transformational leadership style of the auditor in leading the transformation process towards adopting international standards in accounting, with an indication of what are the benefits that will accrue to the economic unit.

2. Shedding light on the skills and experiences of the auditor in marketing himself to workers in the various departments of the economic unit, particularly in the accounting departments. Self-marketing entails the acceptance of all his intellectual proposals related to the need to shift towards adopting international standards.

\section{Study Model}

The model of our study is evident through Figure (1), where it is evident that the adoption of the transformational leadership theory and the arts of self-marketing is in order to enhance the role of the auditor (external or internal) to implement the control and audit tasks in the economic unit in accordance with the ethics of the profession and international accounting standards. 


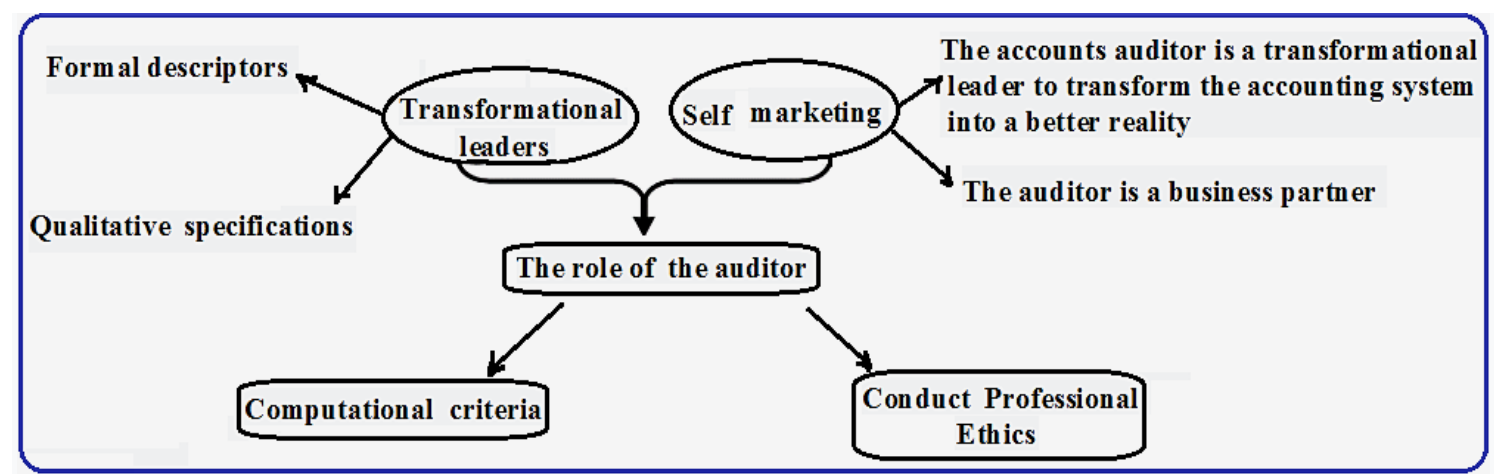

Fig. 1. The General form of the Study that was Adopted in Researching the Details of the Problem ${ }^{(1)}$

Study population and sample: The study population and sample can be clarified through the following figure (2):

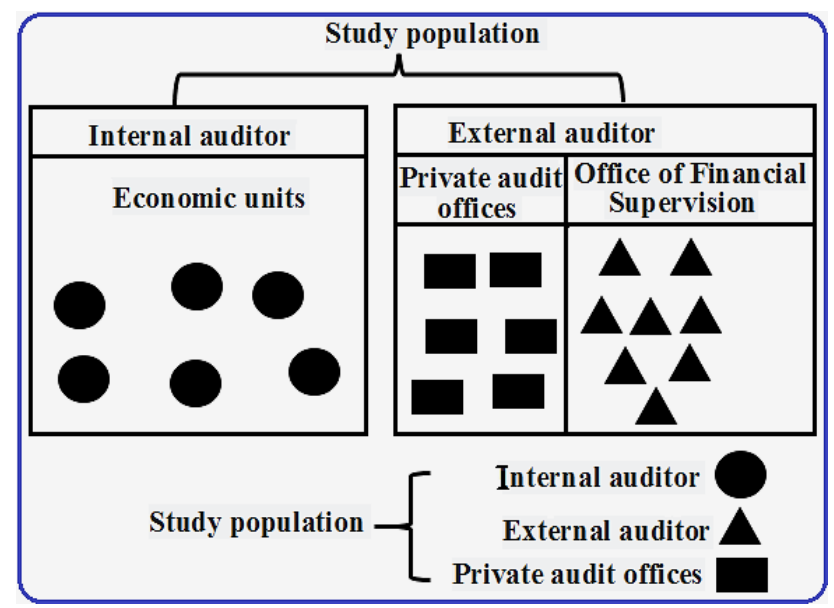

Fig. 2. The Study Population and Sample

From Figure (2) above, which illustrates the study population and sample, we note the following:

First: the study population, where the study population was approved, which consists of each of:

1. The external auditor, who works within the formations of the Federal Financial Supervision Bureau within the various sectors.

2. External auditor, which means the private auditing offices, who is known as the chartered accountant, who is responsible for auditing the accounts of private companies and non-governmental business organizations.

3. The internal auditor, who works in the economic units as a monitor of accounts for all economic activities and all spending and spending operations in them.

Second: The study sample, in which a group of account auditors known as external and internal, as follows:

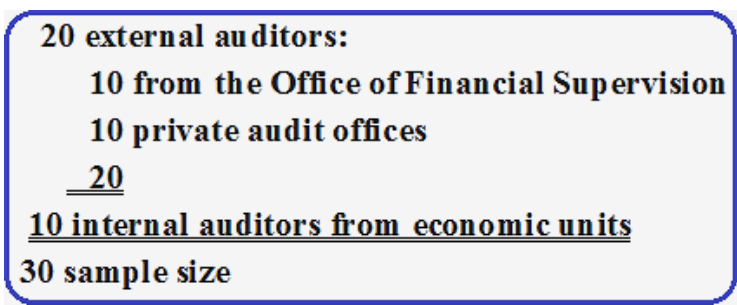

Thus, the meat of the sample is (30). Of all the relevant auditors and auditors who are supposed to have the transformational leadership capacity and possess the arts of self-marketing in the economic unity community. 


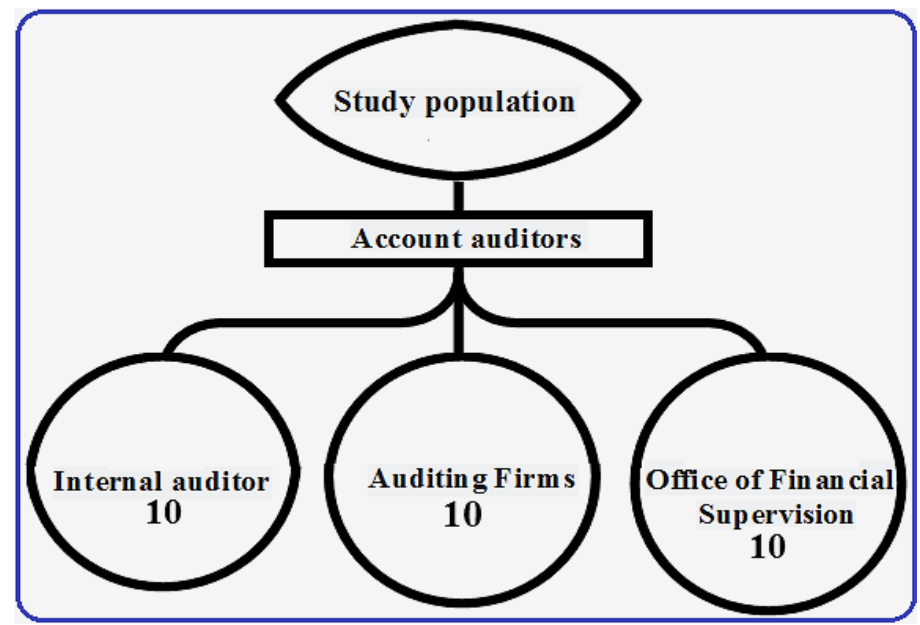

\section{The Second Part: The Intellectual Framework of the Study}

\section{Transformational Leadership/Core Behaviors}

Leadership is an administrative activity practiced to maximize productivity, stimulate innovation in solving problems, raise morale and satisfaction, and it is also known as influencing the activities of the individual and group in order to achieve a specific goal in a particular situation and it is also the art of mobilizing others efficiently and seriously in order to achieve the desired goals. Specialists in managerial leadership problems offer four scientific theories of leadership (The Theories of Managerial Leadership), namely:

1. Leadership trait theory: It focuses on the organic and social functions of the person, as well as the personal standards in determining the characteristics and skills. This theory was based on the concept of group life, and also based on the theory that leaders are born and not made, when a person is born either Possesses or does not possess the traits necessary to drive ${ }^{(2)}$

2. Behavioral leadership theory: This theory is based on two main axes, the first relates to the leader's interest in the same work and its specifications, and the other to the leader's interest in workers and their behavior within the organization.

3. With the emphasis that the leader's behavior can be effective and influential if it relies on the communications that form the link between the leader and the subordinate.

4. Situational leadership theory (contingency): This theory is based on the influence of the external environment and the attitudes under a specific circumstance or event for the emergence of leaders, in other words that the position determines the style of leadership that the leader should adopt.

5. Modern leadership theory: These theories appeared during the last years of the twentieth century as a serious introduction to leadership (3), namely: Capon added four leadership styles to modern leadership theory, according to Table 1, focusing on the main characteristics of those styles:

Table 1. Focusing on the Main Characteristics of those Styles

\begin{tabular}{ll}
\hline Leadership Styles & \multicolumn{1}{c}{ Main Characteristics } \\
\hline Charismatic & - Charismatic leaders focus on team building and creating strong group images. \\
leadership & • Urging environmental scanning processes and then good handling of various cases \\
& - Leaders here look to the involvement of subordinates and others in the decision-making \\
Participatory & process \\
leadership & - The participation of subordinates in the decision-making process helps to improve \\
& understanding of potential problems and decision implementation issues \\
& - Transactional leadership is primarily based on rewards and penalties and is linked to \\
& managers who establish authority over subordinates. \\
Transactional & - These results came through an agreed contract between managers and subordinates, that \\
leadership & $\begin{array}{l}\text { is, giving them wages for effort, and thus the authority of the company's earnings over the } \\
\text { subordinates in the workplace. }\end{array}$ \\
& - Transactional leaders do better when there is a clear chain of rewards and punishments. \\
Transformational & - Transformational leaders see the possibility of developing a strategic vision for the \\
Leadership & organization with high confidence in subordinates to achieve it. \\
& - Transformational leaders are charismatic but have less belief than charismatic leaders \\
& themselves and thus recognize successful outcomes.
\end{tabular}


From the above table the topic of transformational leadership is deduced as it is emphasized in our current field of study. The basic dimensions of transformational leadership and the basic behaviors associated with it are as follows:

\section{The Ideal Influence}

It is the first dimension of transformational leadership that focuses on behavior that captures the admiration of subordinates and subordinates and is carried out with the organization's vision and sense of its mission, and instills a spirit of pride in them and thus attains their respect and trust. A number of associated characteristics were diagnosed With the perfect effect ${ }^{(4)}$ :

1. Integrity as it relates to it a explicit commitment to honesty.

a. The practices are consistent with the organization's policy and concern for ethical behavior.

b. Coordination of actions and behaviors.

2. Liability / Compliance: This means the following:

a. Commitment to teamwork to achieve the desired goals.

b. Show courage and self-confidence in defending beliefs and ideas.

c. Show personal responsibility.

\section{Inspirational Motivation}

This is intended to create a future vision that will encourage subordinates and push them to perform beyond expectations. In this context, an explanation of the transformational leader's role and his tasks in motivating and inspiring subordinates has been added, as is evident in Figures:

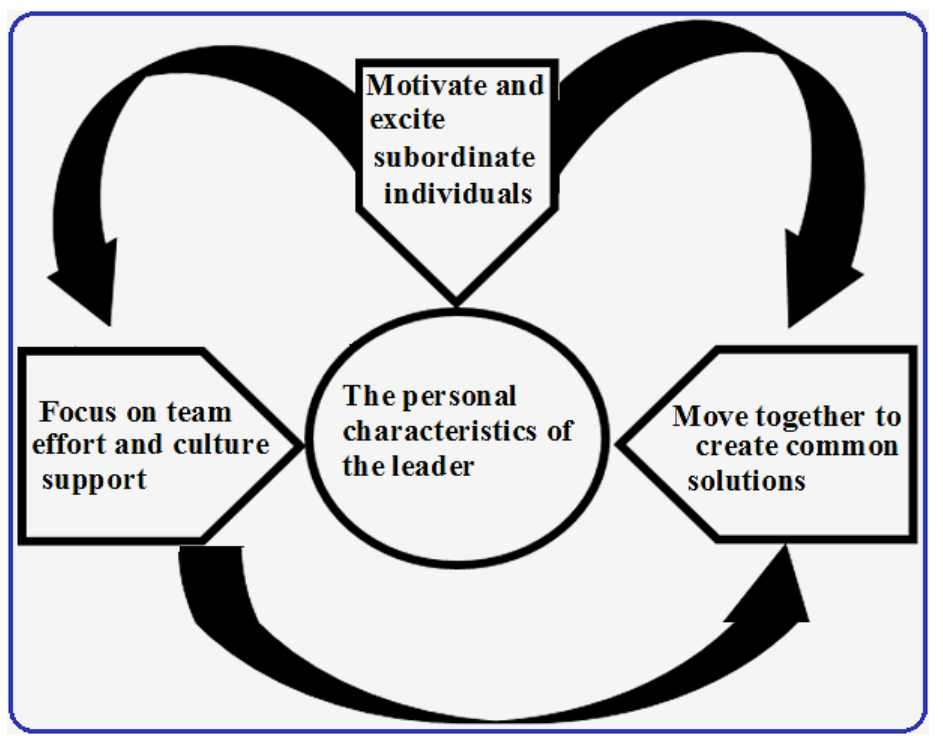

Fig. 3. The transformational leader's role in motivating and inspiring subordinates

\section{Intellectual Arousal}

This also means intellectual stimulation for subordinates to come up with innovative and creative solutions to problems, as based on the above, what is meant by intellectual arousal is for the transformational leader to work on the development of intellectual convictions and mental and behavioral preparations for subordinates to positively deal with the continuous changes in the external environment. Unstable in order to make good decisions.

\section{Individual Considerations}

Accordingly, the transformational leader gives special attention to subordinates, as he works as a trainer, mentor, and friend who cares about the personal aspects with attention to individual precautions in order to accomplish 
tasks properly. In general, the description of behaviors has been applied to these ideas related to transformational leadership as these behaviors would push towards the success of the leadership role of the decision maker by influencing the behavior of subordinates, as is evident ${ }^{(6)}$ in Table (2):

Table 2. Transformational leadership behaviors

\begin{tabular}{ll}
\hline Characteristic of Behavior & Behavior \\
\hline $\begin{array}{l}\text { The leader is considered an ideal model and skilled in influencing subordinates, as } \\
\text { they respect him and trust him and work to promote work as a team, embracing an } \\
\text { integrated vision of the organization }\end{array}$ & The perfect effect \\
$\begin{array}{l}\text { Motivating subordinates to achieve the new vision and future of the organization, } \\
\text { while clarifying high expectations for the performance of subordinates that ensure the }\end{array}$ & $\begin{array}{l}\text { Inspirational } \\
\text { stimulation }\end{array}$ \\
$\begin{array}{l}\text { achievement of organizational goals, and encouragement towards teamwork } \\
\text { Encouraging subordinate leaders to adopt new ideas because they encourage creativity } \\
\text { ifferent angles, taking into account not to ridicule the opinions of subordinates. }\end{array}$ & $\begin{array}{l}\text { Intellectual } \\
\text { arousal }\end{array}$ \\
$\begin{array}{l}\text { It means the personal leader's interest in his subordinates, the awareness of individual } \\
\text { differences, and dealing with each one of them in a specific way and focusing on } \\
\text { training and guiding them to achieve further growth and development. }\end{array}$ & $\begin{array}{l}\text { Individual } \\
\text { considerations }\end{array}$
\end{tabular}

\section{Elements of Transformational Leadership}

Transformational leadership plays an important role in all areas of life. Professors (Tracw \& Hinkan, 1998: 220) stated that the importance of transformational leadership is demonstrated by providing the advantages associated with three elements of the organization:

1. Creating new visions: through the organization's mission and strategies. One of the most important problems that the leader faces is how to draw a strategy that fits the product or service provided by the organization.

2. Designing the organizational structure: The leader's task is to design the organizational structure that meets the needs of the external environment and that allows the organization to achieve its mission effectively.

3. Human Resources Management: The basic goal of designing the human resource system is to achieve compatibility between subordinates and their roles by defining standards for all the activities of the organization, and how to define the activities necessary to achieve the organization's tasks through manpower, and then achieve its goals, while mcshane \& glinow explained (2005: 429) several attributes of transformational leadership focusing on three elements of the following ${ }^{(7)}$.

1. Create a strategic vision.

2. Communicating the vision to the workers.

3. Building a commitment to the vision.

Transformational leadership is related in one way or another to the topic of self-marketing to the leader, that is, how the transformational leader can market himself, and this we will get to know in the paragraph below.

\section{Self-Marketing Arts}

The word (arts) was launched on the grounds that this topic is related to the skills of workers in the field of service marketing, as in general the marketing function is no longer the easy process that the organization or individual undertakes by offering the commodity or service to the consumer to buy it, so marketing has passed.

It became the practical lifeline that passes through the veins of successful organizations. Without good marketing, regardless of the quality of the product or service, the efficiency of sales becomes less effective and less effective, noting that marketing is what determines the price of the product or service, and it also introduces the consumer to the features and heart that characterizes the product and its suitability to the needs of the consumer. All these ideas depend mainly on the same person who is responsible for the service marketing process, as due to the multiplicity and complexity of the different means of life, the need for multiple and varied personal and functional skills has increased for people who want to successfully market themselves ${ }^{(8)}$. Mala distinguishes this process because it is related to the behavioral characteristics of the same person, so it is known 
as the personal marketing process, As this process is characterized by its dependence on a two-way communication method, that is, the marketer can notice the customer's reaction to the ideas he proposes, and he can provide an explanation of the ambiguous matters. Which reflects his opinion and point of view. And this problem depends mainly on the personality of the salesman and the person responsible for this task and the personality of individuals is considered the basis for the process of self-marketing, as it was defined as a set of personal, muscle, physical and moral characteristics that the person himself found (Al-Hassan, 2009: 87) and (Al-Wardi, 1999: 52). The character was also known as a group, It is one of the inherent physiological and psychological characteristics that define the individual's identity, and these characteristics include his external appearance and the way he thinks, acts and feels as they are all the result of the interaction between genes and the environment (Al-Masry, 2006).

The self can be marketed by adopting the following methods that refer to the self-arts owned by the salesman (Malhorta, 2010: 183), which are as follows:

1. The individual has to break down the barriers between himself and others as a first step towards selfmarketing.

2. Participating with others and helping them with offering services to them, as this is one of the marketing lines, as helping others paints a good picture for service providers, and their assistance reveals the skill of service providers and informs customers a message about the possibility of continuing to deal in the future.

3. The initiative to communicate with others in order to introduce them to the work and skills of service providers with tact and intelligence.

4. Striving to expand the circle of knowledge, as this will bring more opportunities and transform the service provider's reputation into a brand.

5. Not to be shy about mentioning different services previously provided by the service provider, because this will be added to the balance of previous experiences and CV.

6. The service provider must be a self-insurer so that others can believe in his capabilities.

7. Paying attention to the external appearance, as one of the basic components of the service provider's selfmarketing process.

8. Educating for the direction of an important fact, which is that success at work does not depend only on the professional experience and academic excellence of the salesman, but also on the ability to market oneself.

9. Acknowledging an important truth, which is that self-marketing does not mean flattery and gaining the approval of superiors, but rather presenting the outstanding qualities that the service provider possesses coupled with humility.

10. Socially successful personalities are best able to understand the requirements of self-marketing and its arts.

11. Belief in an important truth, which is that no one believes in their ideas if they are not effectively marketed, and that the people who excel in self-marketing are the emotionally intelligent people.

12. Writing a CV for any individual in a distinctive way makes him the best in the process of self-marketing, and the $\mathrm{CV}$ can be published on social media as an advanced method in self-marketing.

Based on the foregoing, specialists in literary sciences go to the link between the concepts of self-marketing and the topic of body language, and this is what we will learn about below.

\section{Body Language and its Role in Self-marketing ${ }^{(9)}$}

The body language is mainly based on the language of the face, as well as the language of the rest of the body, as it is known that the face and movements of the rest of the body parts of any person have language, and readable expressions. As researchers in psychology and sociology go to the opinion that the face is a mirror of the same person and at the same time it is a window of this self to the outside world. Therefore, psychologists specializing in facial features go to present a definition of the concept of facial language, as that scientific discipline that is concerned with studying the relationship between features of facial movements and the psyche of the individual. Some interpret it as a predictive art and not as (S. Corman) believes that it is a dynamic science based on the link between biological guidance and psychological guidance, and the latter provided its interpretation and analysis of the location of facial features, as the place where the living forces of the individual grapple with the forces of the environment Foreign Affairs, including its members from different societies. 


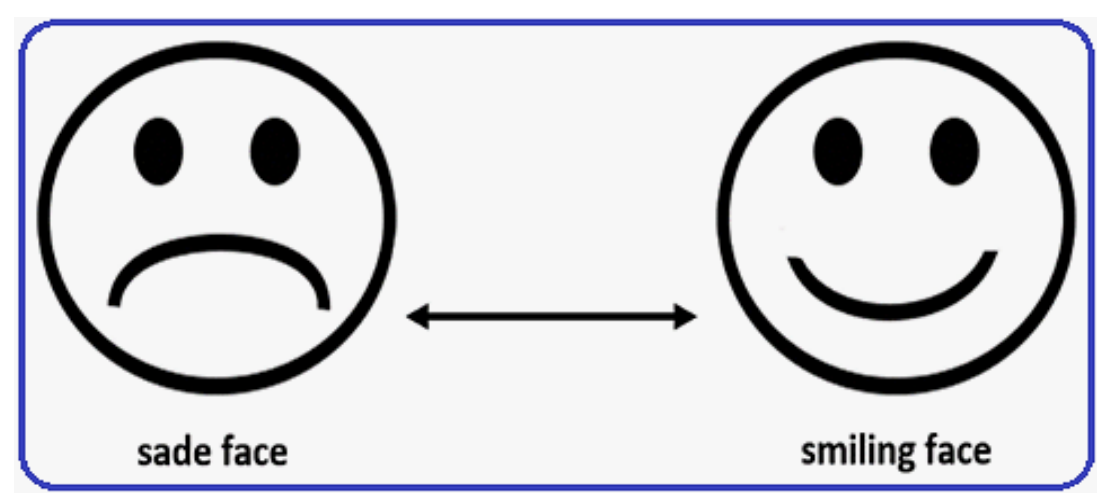

Fig. 4. The aspects that express the psychological state of the individual

The face is the basis in the process of communication between individuals in the midst of a certain society, as studies have given the largest percentage of influence on others, the tongue may lie several times, as for the face and especially the eyes, they refer to the reality of self-feelings and knowing the other through the face helps a lot in the relationship with the party The other and understand what he is hiding. In general, body language specialists present two types of faces, each of which illustrates a specific psychological and behavioral state, as is evident in Figure (4), as follows:

First: the smiling face

Second: the sad face

And between this and that, there may be a space for different types of faces to enter, with a neutral face in the middle as shown in Figure (4).

\section{International Accounting Standards}

During the nineties of the twentieth century, trends appeared towards a real economy in which many American companies achieved a significant amount of their revenues and profits in foreign markets. Multinational companies face some decisions related to the distribution of resources among the most efficient uses available to them, and these distributions cannot be achieved without the presence of information Accurate and reliable, companies seeking to obtain capital or investment opportunities across borders face time and cost problems, as these companies must reconcile their financial statements with the accounting rules of the country in which they seek capital. Financial accounting is affected by the environment in which it operates, and different nations have different histories, values, cultures, and different political and economic systems, and also differ in the degree of economic growth, and these national influences interact with each other, and in turn affect the development and application of financial accounting practices and reporting procedures, and in view of the aforementioned national differences The financial accounting standards that are applied to the accounting data in different multinational companies differ clearly, despite the differences from one country to another.

The companies prepare financial reports primarily intended for their main employees, and most of these users were previously residents of the same country in which the company publishes the financial statements, but the emergence of multinational companies and organizations such as the European Union (EU) and the General Agreement on Trade and Customs Tariffs (GATT) and North American Free Trade Agreement (NAFTA) make the transnational financial reporting process more widespread, and cross-border financial reporting requires an understanding of its user of the accounting practices used by the company.

Here, the role of transformational leadership and self-marketing appears, in addition to what language it relies on and the currency it uses to prepare its financial statements. If investors and lenders are not able to obtain information, they can understand it about companies operating in a foreign country, where they are unlikely to invest there is a tendency towards harmonizing accounting standards in different countries.

In general, there is a direct correlation between the level of education and culture, as well as the presence of elements possessing transformational leadership skills and the arts of self-marketing in the country in which the application of international standards is required. In addition to this, factors that express some of the external environment elements of the following economic unit:

1. Political System: The political system (socialist, democratic, totalitarian, etc.) can affect the development of accounting standards and procedures. The accounting system in a country with a centralized control economy 
will be different from the accounting system in a market economy, it may require companies in socialist towns, for example, to provide information on the social impact and cost-benefit analysis as well as profitability and financial position information.

2. Legal System: The degree to which the state's law defines the accounting practice affects the strength of the accounting profession in it. When the government describes accounting practices and procedures, the authority of the accounting profession is relatively weak, while the illegal establishment of accounting policies by the profession's organizations is a feature of the countries that adopt Public Law.

3. Economic Development: The level of economic development of the country affects both the application and development of the practices of the accounting development process and the orientation towards international standards. A country with low levels of economic development will need complex accounting systems relatively less than the need for a country with high levels of economic development for such systems.

\section{The Factors that Contributed to Establishing the International Accounting Standards (IAS)}

There are a number of factors, which can be explained as follows:

1. Rapid growth in the international capital markets, along with the increase in registration, listing and cross-border investments, and greater achievement of comparison in the financial report.

2. Efforts of international organizations (such as the World Trade Organization (WTO) and regional bodies (such as the European Union and the North American Free Trade Agreement) to remove barriers to international trade.

3. The general trend towards an international (globalization) business organization.

4. The increasing impact of international accounting standards on accounting requirements and practices at the national level.

5. Acceleration of modernization and innovation in business enterprise processes.

6. Increasing user demand for new types of financial and other performance information.

7. The increasing need for adequate financial information and other performance information in every country transitioning from a centrally planned economy to a market economy.

8. The pressures of multinational companies towards the need for compatible standards around the world to disclose their financial positions through reports, as the branches of companies are spread in most countries and operate in a variety of different environments and one of the difficulties they face is the completion of their financial reports according to the local standards of those operating countries In it, therefore, it is in its interest for the countries of the world to apply unified standards according to which they must prepare their financial statements.

In this regard, the following must be clarified:

\section{First: The International Accounting Standards Committee IASC}

It is an independent organization that aims to prepare standards that can be used by institutions when preparing financial statements in various parts of the world. The date of the beginning of the adoption of international standards goes back to the month of June of 1973 when a special committee was established for that matter. It was named the International Accounting Standards Committee before it was restructured, and the committee's membership includes all the (1439) international accounting organizations (1439) affiliated associations (103) countries according to an agreement concluded between the countries that are pioneers in the field of effective accounting. In each of (Australia, Canada, France, Germany, Japan, Mexico, the Netherlands, the United Kingdom, Ireland, the United States of America), and as a result, a board was formed to manage this committee, consisting of representatives from the accounting bodies accredited to the member states. The International Accounting Standards Board (IASB), which became responsible for issuing international accounting standards, starting from April 2001.

\section{Second: International Standards Board (IASB)}

It is a professional council for setting international standards based in London and responsible for issuing and developing standards. The result of the restructuring of the (IASC) committee in the year 2001 came under the name of expanding its responsibilities and concerned with the abolition and amendment of previous standards, as 
well as their interpretations and until they are modified or withdrawn and the introduction of new standards called standards International Financial Reporting (IFRS).

The International Accounting Standards Board aims to:

1. Establishing high-quality standards that can be understood and applied and to prepare financial statements in a way that helps them to be adopted in the global capital markets (unified international language).

2. Preparing accounting standards suitable for application in all countries of the world, through which financial statements are prepared that enjoy high transparency, can be trusted and are appropriate for their user.

\section{Professional Ethics (Rules of Professional Conduct)}

The auditor, in light of the professional reality in any economic system or any country, must be governed by controls. Deterrents are different, the most important of which is related to the rules of professional conduct or what is known as professional ethics, which strengthens his role as a leader in the position in which he works as an auditor of accounts, and most countries (including Iraq) have adopted these controls in order to be the auditor.

1. Independent and impartial in all of the sites and the problems presented to it.

2. Free from any self-interest.

3. Act with high objectivity and honesty.

The controls presented in the rules of professional conduct have clarified a group of behaviors prohibited to the auditor, paragraph (3) of Article 4 and paragraph (2) of Article 5 of the Law of the Iraqi Accountants and Auditors Association No. (185) of 1919, as the Bar Council later approved on some basis Rules of professional conduct are presented according to the session numbered (18) on $12 / 12 / 1983{ }^{(9)}$ that the actions of the auditor give indications of the extent of follow-up and accuracy of the auditor's behavior and the emphasis on being a transformational leader else.

All scientific formulas of professional conduct rules that must be adopted and applied in relation to the auditor, are required to have the following:

1. Preserving the position and reputation of the auditor, as it is a source of confidence for all parties.

2. Preserving the secrets of the economic unit in which the monitoring and auditing process takes place.

3. Preserving the general rights of the state (the public right) without having loopholes that weak-minded people can penetrate.

4. Displaying an appropriate picture of the political and economic reality of the country in which these matters are taking place.

5. Balancing the interests of all parties related to the control and auditing process.

From the foregoing, it is clear that the ethics of the profession and the rules of professional conduct exist for the sake of advancing the accounting profession and strengthening the role of the auditor in all economic units in which work is carried out.

\section{The Third Part: The Practical Side of the Study}

\section{Local Standards Used in Iraq}

Iraq has adopted many local standards that are compatible with the country's economic policies.

Issued by the Accounting and Supervisory Standards Board in Iraq, which was established on the basis of a proposal by the Office of Financial Supervision in the year 1988, and the functions of the Board were defined by several matters that are summarized below:

1. Study, develop, and approve accounting and regulatory standards.

2. Express opinion on draft laws and accounting and control systems contained in other draft laws.

3. Proposing amendments to accounting and regulatory legislation. 
4. Coordination and cooperation with international and professional institutions and organizations inside and outside Iraq.

Since the council was established, it has accomplished many important matters that specialize in the profession of accounting and auditing, and has developed their own solutions, as it issued (14) accounting rules and (6) audit oversight guides.

It should be noted here that most of the accounting standards used in Iraq are mostly a translation of international accounting standards, but the only difference is that no amendments have been made to them, reformulated and interpreted, but the only difference is that no amendments have been made to them, reformulated and interpreted in order to be compatible with the global economic environment and The rapid developments that I have obtained, as well as the development in the field of information technology, and examples of the differences that may occur in the standards related to financial reports and the way of presenting financial data and disclosure to find out their suitability for international institutions and companies It is the use of the principle of the historical cost or the market value of the assets when preparing the final accounts, as well as the various methods of extinction, the use of any of them, and their disclosure, as well as the methods of treating reserves, allocations, and all intangible assets. Our research focuses on the standard role and self-marketing skills of the auditor in the transition towards international standards.

\section{An Opinion Poll about the Leadership Role of the Auditor and his Self-marketing Arts}

Where a pilot study was designed for this purpose, where the questions about the idea of the topic were divided into two parts:

The first concerns the transformational leadership of the auditor.

The second relates to the skills or arts of self-marketing for the auditor.

The questions were formulated within the first section into four axes, namely:

- The axis related to the ideal influence of the auditor.

- The axis related to inspirational motivation for the auditor.

- The axis related to the intellectual arousal of the auditor.

- The axis on the individual considerations of the auditor.

As for the second part, which is related to the skills and arts of self-marketing, the questions were divided into two main axes, namely:

First: Self-marketing of the auditor towards the internal environment in the economic unit.

Second: Self-marketing of the accounts auditor towards the external environment, particularly towards the supervisory agencies of the state or the private sector.

The questionnaire was distributed to the study sample and was collected and analyzed using the statistical program SPSS, and the answers were obtained in which the arithmetic mean, standard deviation and weight percentile were calculated, as shown below.

\section{Data Analysis and Final Results Extraction}

The data were arranged and analyzed, and the arithmetic mean, standard deviation and percentage weight of the study sample answers were calculated as in the table below:

First: Questions related to the role of transformational leadership in enhancing the role of the auditor in adopting international standards

\section{Analysis of the Ideal Effect}

Table No. (3) the arithmetic mean, the standard deviation, and the relative importance of the answers of the sample members $n=(30)$ 
Table 3. The arithmetic mean, the standard deviation, and the relative importance

\begin{tabular}{|c|c|c|c|c|c|c|c|c|c|c|}
\hline \multirow{2}{*}{$\begin{array}{c}\text { Order of } \\
\text { importance }\end{array}$} & \multirow{2}{*}{$\begin{array}{c}\text { Weight } \\
\text { percentile }\end{array}$} & \multirow{2}{*}{$\begin{array}{l}\text { Standard } \\
\text { deviation }\end{array}$} & \multirow{2}{*}{$\begin{array}{c}\text { arithmetic } \\
\text { mean }\end{array}$} & \multicolumn{5}{|c|}{ Levels of response } & \multirow{2}{*}{ Q. No } & \multirow{2}{*}{$\begin{array}{l}\text { The focus of } \\
\text { the questions }\end{array}$} \\
\hline & & & & \begin{tabular}{|c|} 
not \\
strongly \\
Agreed
\end{tabular} & $\begin{array}{c}\text { not } \\
\text { Agreed }\end{array}$ & Neutral & Agreed & $\begin{array}{l}\text { strongly } \\
\text { Agreed }\end{array}$ & & \\
\hline 1 & 70.50 & 0.93 & 3.99 & 4 & 6 & 0 & 9 & 11 & 1 & \multirow{6}{*}{$\begin{array}{l}\text { The ideal } \\
\text { effect for } \\
\text { an auditor }\end{array}$} \\
\hline 2 & 72.31 & 0.81 & 4.11 & 0 & 3 & 3 & 10 & 15 & 2 & \\
\hline 5 & 77.50 & 0.83 & 4.30 & 0 & 3 & 3 & 12 & 12 & 3 & \\
\hline 4 & 66.20 & 0.73 & 3.92 & 2 & 3 & 0 & 12 & 13 & 4 & \\
\hline 3 & 71.60 & 0.92 & 4.22 & 2 & 2 & 4 & 12 & 10 & 5 & \\
\hline 2 & 80.40 & 0.91 & 4.51 & 0 & 5 & 0 & 11 & 14 & 6 & \\
\hline 3 & 84.83 & 0.85 & 4.17 & \multicolumn{5}{|c|}{$\begin{array}{l}\text { The arithmetic mean, Standard } \\
\text { deviation, and Weight per centile }\end{array}$} & \multicolumn{2}{|c|}{$\begin{array}{l}\text { Average statistical } \\
\text { indicators }\end{array}$} \\
\hline
\end{tabular}

\section{Analyzing the Ideal Stimulus}

Table No. (4) The arithmetic mean, the standard deviation, and the relative importance of the answers of the sample members $\mathrm{n}=(30)$

Table 4. The arithmetic mean, the standard deviation, and the relative importance

\begin{tabular}{|c|c|c|c|c|c|c|c|c|c|c|}
\hline \multirow[b]{2}{*}{$\begin{array}{c}\text { Order of } \\
\text { importance }\end{array}$} & \multirow{2}{*}{$\begin{array}{c}\text { Weight } \\
\text { percentile }\end{array}$} & \multirow{2}{*}{$\begin{array}{l}\text { Standard } \\
\text { deviation }\end{array}$} & \multirow{2}{*}{$\begin{array}{c}\text { arithmetic } \\
\text { mean }\end{array}$} & \multicolumn{5}{|c|}{ Levels of response } & \multirow{2}{*}{ Q.No } & \multirow{2}{*}{$\begin{array}{l}\text { The focus of } \\
\text { the questions }\end{array}$} \\
\hline & & & & \begin{tabular}{|c|} 
not \\
strongly \\
Agreed
\end{tabular} & $\begin{array}{c}\text { not } \\
\text { Agreed }\end{array}$ & Neutral & Agreed & $\begin{array}{l}\text { strongly } \\
\text { Agreed }\end{array}$ & & \\
\hline 5 & 77.30 & 0.88 & 4.20 & 2 & 2 & 8 & 8 & 10 & 1 & \multirow{6}{*}{$\begin{array}{l}\text { The ideal } \\
\text { effect for } \\
\text { an auditor }\end{array}$} \\
\hline 2 & 71.50 & 0.81 & 3.98 & 1 & 1 & 3 & 11 & 14 & 2 & \\
\hline 3 & 68.70 & 0.92 & 4.11 & 2 & 3 & 2 & 8 & 12 & 3 & \\
\hline 1 & 67.40 & 0.72 & 4.00 & 1 & 2 & 8 & 9 & 10 & 4 & \\
\hline 4 & 80.30 & 0.91 & 4.31 & 2 & 3 & 5 & 10 & 10 & 5 & \\
\hline 2 & 79.71 & 0.87 & 4.32 & 0 & 5 & 0 & 10 & 15 & 6 & \\
\hline 3 & 74.16 & 0.85 & 4.15 & \multicolumn{5}{|c|}{$\begin{array}{l}\text { The arithmetic mean, Standard } \\
\text { deviation, and Weight percentile }\end{array}$} & \multicolumn{2}{|c|}{$\begin{array}{l}\text { Average statistical } \\
\text { indicators }\end{array}$} \\
\hline
\end{tabular}

\section{Intellectual Arousal Analysis}

Table No. (5) The arithmetic mean, the standard deviation, and the relative importance of the answers of the sample members $\mathrm{n}=(30)$

Table 5. The arithmetic mean, the standard deviation, and the relative importance

\begin{tabular}{|c|c|c|c|c|c|c|c|c|c|c|}
\hline \multirow[b]{2}{*}{$\begin{array}{c}\text { Order of } \\
\text { importance }\end{array}$} & \multirow[b]{2}{*}{$\begin{array}{c}\text { Weight } \\
\text { percentile }\end{array}$} & \multirow{2}{*}{$\begin{array}{l}\text { Standard } \\
\text { deviation }\end{array}$} & \multirow{2}{*}{$\begin{array}{c}\text { arithmetic } \\
\text { mean }\end{array}$} & \multicolumn{5}{|c|}{ Levels of response } & \multirow{2}{*}{ Q.No } & \multirow{2}{*}{$\begin{array}{l}\text { The focus of } \\
\text { the questions }\end{array}$} \\
\hline & & & & $\begin{array}{l}\text { not } \\
\text { strongly } \\
\text { Agreed }\end{array}$ & $\begin{array}{c}\text { not } \\
\text { Agreed }\end{array}$ & Neutral & Agreed & $\begin{array}{l}\text { strongly } \\
\text { Agreed }\end{array}$ & & \\
\hline 1 & 68.70 & 0.77 & 4.30 & 1 & 2 & 3 & 10 & 14 & 1 & \multirow{6}{*}{$\begin{array}{l}\text { The ideal } \\
\text { effect for } \\
\text { an auditor }\end{array}$} \\
\hline 2 & 67.77 & 0.78 & 4.12 & 0 & 1 & 7 & 12 & 10 & 2 & \\
\hline 2 & 81.30 & 0.81 & 4.22 & 2 & 2 & 6 & 10 & 10 & 3 & \\
\hline 2 & 80.11 & 0.88 & 3.98 & 2 & 4 & $\mathbf{0}$ & 11 & 13 & 4 & \\
\hline 3 & 77.90 & 0.92 & 3.99 & 3 & 4 & 3 & 8 & 12 & 5 & \\
\hline 4 & 72.40 & 0.89 & 4.10 & 0 & 1 & 3 & 10 & 16 & 6 & \\
\hline 2 & 74.69 & 0.84 & 4.11 & & $\begin{array}{l}\text { rithm } \\
\text { tion, a }\end{array}$ & $\begin{array}{c}c \text { mean } \\
\text { Weigl }\end{array}$ & $\begin{array}{l}\text { tandar } \\
\text { ercercen }\end{array}$ & & $\begin{array}{l}\text { Aver } \\
\text { ind }\end{array}$ & $\begin{array}{l}\text { ge statistical } \\
\text { ators }\end{array}$ \\
\hline
\end{tabular}




\section{Analyzing Individual Considerations}

Table No. (6) The arithmetic mean, the standard deviation, and the relative importance of the answers of the sample members $n=(30)$.

Table 6. The Arithmetic Mean, the Standard Deviation, and the Relative Importance

\begin{tabular}{|c|c|c|c|c|c|c|c|c|c|c|}
\hline $\begin{array}{c}\text { Order of } \\
\text { importance }\end{array}$ & $\begin{array}{c}\text { Weight } \\
\text { percentile }\end{array}$ & $\begin{array}{c}\text { Standard } \\
\text { deviation }\end{array}$ & $\begin{array}{c}\text { arithmetic } \\
\text { mean }\end{array}$ & $\begin{array}{c}\text { Lot } \\
\text { strogly } \\
\text { Agreed }\end{array}$ & $\begin{array}{c}\text { not } \\
\text { Agreed }\end{array}$ & Neutral & Agreed & $\begin{array}{l}\text { strongly } \\
\text { Agreed }\end{array}$ & Q.No & $\begin{array}{l}\text { The focus of } \\
\text { the questions }\end{array}$ \\
\hline 2 & 77.33 & 0.89 & 4.21 & 0 & 1 & 7 & 12 & 10 & 1 & \\
\hline 3 & 79.91 & 0.83 & 4.33 & 1 & 2 & 2 & 12 & 13 & 2 & $\begin{array}{l}\text { The ideal } \\
\text { effect for } \\
\text { an auditor }\end{array}$ \\
\hline 1 & 87.72 & 0.77 & 3.99 & 0 & 2 & 3 & 10 & 15 & 3 \\
\hline 4 & 80.94 & 0.72 & 3.98 & 1 & 3 & 4 & 12 & 10 & 4 \\
\hline 2 & 84.92 & 0.79 & 4.11 & 1 & 1 & 0 & 14 & 14 & 5 \\
\hline 5 & 88.49 & 0.91 & 4.25 & 0 & 0 & 6 & 10 & 14 & 6 \\
\hline 3 & 81.71 & 0.81 & 4.14 & \multicolumn{7}{|c|}{$\begin{array}{l}\text { The arithmetic mean, Standard } \\
\text { deviation, and Weight percentile }\end{array}$} \\
\hline
\end{tabular}

Second: Questions related to the role of the arts of self-marketing in enhancing the task of the auditor in adopting international standards.

1. Self-marketing of the Auditor towards the External environment.

Table No. (7) The arithmetic mean, the standard deviation, and the relative importance of the answers of the sample members $n=(30)$.

Table 7. The arithmetic mean, the standard deviation, and the relative importance

\begin{tabular}{|c|c|c|c|c|c|c|c|c|c|c|}
\hline \multirow{2}{*}{$\begin{array}{r}\text { Order of } \\
\text { importance }\end{array}$} & \multirow[b]{2}{*}{$\begin{array}{c}\text { Weight } \\
\text { percentile }\end{array}$} & \multirow[b]{2}{*}{$\begin{array}{l}\text { Standard } \\
\text { deviation }\end{array}$} & \multirow[b]{2}{*}{$\begin{array}{c}\text { arithmetic } \\
\text { mean }\end{array}$} & \multicolumn{5}{|c|}{ Levels of response } & \multirow{2}{*}{ Q.No } & \multirow[b]{2}{*}{$\begin{array}{l}\text { The focus of } \\
\text { the questions }\end{array}$} \\
\hline & & & & $\begin{array}{c}\text { not } \\
\text { strongly } \\
\text { Agreed }\end{array}$ & $\begin{array}{c}\text { not } \\
\text { Agreed }\end{array}$ & Neutral & Agreed & $\begin{array}{l}\text { strongly } \\
\text { Agreed }\end{array}$ & & \\
\hline 2 & 72.77 & 0.81 & 4.21 & 1 & 1 & 8 & 10 & 10 & 1 & \multirow{6}{*}{$\begin{array}{l}\text { The ideal } \\
\text { effect for } \\
\text { an auditor }\end{array}$} \\
\hline 1 & 73.91 & 0.88 & 3.98 & 0 & 2 & 7 & 11 & 10 & 2 & \\
\hline 5 & 78.92 & 0.83 & 4.50 & 0 & 1 & 1 & 12 & 16 & 3 & \\
\hline 4 & 71.93 & 0.84 & 4.11 & 1 & 4 & 5 & 10 & 10 & 4 & \\
\hline 2 & 80.41 & 0.79 & 4.26 & 0 & 1 & 2 & 13 & 14 & 5 & \\
\hline 3 & 82.42 & 0.77 & 3.99 & 1 & 2 & 1 & 14 & 12 & 6 & \\
\hline 3 & 76.72 & 0.82 & 4.17 & \multicolumn{5}{|c|}{$\begin{array}{l}\text { The arithmetic mean, Standard } \\
\text { deviation, and Weight percentile }\end{array}$} & \multicolumn{2}{|c|}{$\begin{array}{c}\text { Average statistical } \\
\text { indicators }\end{array}$} \\
\hline
\end{tabular}

2. Self-marketing of the auditor towards the internal environment., Table No. (8) the arithmetic mean, the standard deviation, and the relative importance of the responses of the sample members $n=(30)$

Table 8. The Arithmetic Mean, the Standard Deviation, and the Relative Importance

\begin{tabular}{|c|c|c|c|c|c|c|c|c|c|c|}
\hline \multirow{2}{*}{$\begin{array}{c}\text { Order of } \\
\text { importance }\end{array}$} & \multirow{2}{*}{$\begin{array}{c}\text { Weight } \\
\text { percentile }\end{array}$} & \multirow[b]{2}{*}{$\begin{array}{l}\text { Standard } \\
\text { deviation }\end{array}$} & \multirow[b]{2}{*}{$\begin{array}{c}\text { arithmetic } \\
\text { mean }\end{array}$} & \multicolumn{5}{|c|}{ Levels of response } & \multirow{2}{*}{ Q.No } & \multirow[b]{2}{*}{$\begin{array}{l}\text { The focus of } \\
\text { the questions }\end{array}$} \\
\hline & & & & $\begin{array}{l}\text { not } \\
\text { strongly } \\
\text { Agreed }\end{array}$ & $\begin{array}{c}\text { not } \\
\text { Agreed }\end{array}$ & Neutral & Agreed & $\begin{array}{l}\text { strongly } \\
\text { Agreed }\end{array}$ & & \\
\hline 2 & 88.70 & 0.81 & 4.12 & 0 & 1 & 2 & 10 & 17 & 1 & \multirow{6}{*}{$\begin{array}{l}\text { The ideal } \\
\text { effect for } \\
\text { an auditor }\end{array}$} \\
\hline 1 & 81.30 & 0.88 & 4.33 & 1 & 2 & 2 & 13 & 12 & 2 & \\
\hline 3 & 86.24 & 0.91 & 4.51 & 1 & 1 & 3 & 12 & 13 & 3 & \\
\hline 4 & 87.61 & 0.79 & 3.99 & 2 & 1 & 2 & 10 & 15 & 4 & \\
\hline 5 & 77.87 & 0.77 & 3.95 & 1 & 3 & 4 & 12 & 10 & 5 & \\
\hline 1 & 77.80 & 0.78 & 4.21 & 0 & 2 & 3 & 11 & 14 & 6 & \\
\hline 3 & 82.31 & 0.82 & 4.18 & \multicolumn{5}{|c|}{$\begin{array}{l}\text { The arithmetic mean, Standard } \\
\text { deviation, and Weight percentile }\end{array}$} & \multicolumn{2}{|c|}{$\begin{array}{l}\text { Average statistical } \\
\text { indicators }\end{array}$} \\
\hline
\end{tabular}


It is evident from the tables $(3,4,5,6)$ related that the study sample is consistent with the possibility of playing the transformative leadership role of the accounts controller, where in the aforementioned tables clearly the bias towards response levels (strongly agree, agree), that is, the auditor has an important role in the economic unit. To convert to international standards, and this supports the first hypothesis of our study.

From the following tables (Tables No. 7, 8) it becomes clear that there is a possibility for the auditor to play an important role by marketing himself, in other words, the attractive personality and charisma and the correct marketing of these qualities are among the requirements associated with the marketing process of the auditor. Upon entering the arena of work in the economic unit and heading, he survived the application or adoption of international standards, as the paragraph (Strongly Agree and Agree) has a clear weight, as shown in Tables No. (7 and 8) mentioned above.

In addition to the foregoing, such an opinion is based on what was mentioned in the second hypothesis, i.e. it is considered to be fulfilled according to that. Such trends also require workers to understand the importance of applying international standards, given that this is consistent with the major changes in the global economy, and these ideas were supported through the first part of the questionnaire, specifically through the questions directed to workers in the economic unit and the possibility of his acceptance as a transformational leader and acceptance Personality by employees.

\section{Conclusions}

Based on the foregoing, the following conclusions were drawn:

First: There is a clear possibility for the auditor to play the role of a transformational leader in the field of adopting international standards in economic units that may be subject to these standards.

Second: The researchers concluded, based on the aforementioned statistical analyzes, that the arts of selfmarketing, if the auditor is able to employ them appropriately, leads to acceptance of the ideas that he applies towards adopting international standards $\mathrm{g}$, where through body language he can persuade workers in the economic unit.

Third: Workers in accounting units in companies or economic units need the necessary guidance and support with facts and evidence to be convinced of the shift towards adopting international standards, and this is the task of the auditor as a transformational leader.

Fourth: The personal and personal structure of the auditor, in addition to the skills he possesses in the field of transformational leadership, specifically in the field of (ideal influence, inspirational motivation, intellectual stimulation, and individual considerations) are the basis for explaining the requirements of applying or adopting international accounting standards in different economic units.

\section{Recommendations}

In order to acknowledge the importance of transformational leadership and the arts of self-marketing to the auditor, the researchers present the following recommendations:

1. The selection of the auditor must be made according to specific assessments so that it is emphasized that he has leadership skills, especially transformational leadership, in order to be able to lead all stages of the transition process towards adopting international standards.

2. The auditor should enjoy having the tools of self-marketing arts, including knowledge of the origins and rules of body language, in order to influence all influential parties in the economic unit, whether these parties are internal or external.

3. The workers in the accounting units in the economic unit should be prepared and prepared in order to respond to the directions of the auditor when it comes to adopting international standards.

4. Emphasizing that the auditor possesses transformational leadership skills, namely:

- The perfect effect

- Inspirational stimulation

- Intellectual arousal

- Individual considerations 
This is in order to lead the transformation process towards adopting international standards in a scientifically correct manner.

\section{References}

1. Kondalkar, V. (2017). Organizational Behavior 2th, Ed, New International (P), New York, 316.

2. Capon, C. (2008). Understanding Strategic Management. Ashford Colour Press, Ltd, New York, 221.

3. Kouzes, J.M., \& Posner, B.Z. (2010). The Leadership Challenge Activitier. P. Fiefter, Usa, 304.

4. James, H. (2012). Organizational Policy and Strategic Management, 2th, ed., Dryden press, Chicago, 311.

5. Macshane, S. \& Gllinow, M. (2005). Organizational Behavior, Trwin, Mcqraw-Ltill, New York, 42.

6. Ahmed, J.S. (2011). The Role of Transformational Leadership Behaviors in Managing the Organizational Crisis. MA Thesis, College of Administration and Economics, University of Qadisiyah, 70.

7. AL-Mashhadi, A.S.J., \& Al-Fadhel, M.A.K. (2020). The Role of Knowledge Machinery in Supporting Financial and Accounting Transparency in the Economic Unit. Palarch's Journal of Archaeology of Egypt/Egyptology, 17(3), 4129-4154.

8. Muiead A.K. Al-Fadhel. (2018). Self-marketing of medical personnel from a body language perspective / exploratory study. The research is accepted for publication in the proceedings of the fourth conference of the College of Administrative Technology, Baghdad.

9. AL-Mashhadi, A.S.J. (2021). Review on the Internal Control System. Journal of Accounting Research, Business and Finance Management, 2(1).

10. Sabti, K.H. (2014). The readiness of tourism culture and body language to support the administration of religious tourism - a case study in the province of Najaf. Thesis, College of Administration and Economics / University of Kufa, 2014, supervised by Prof. Dr. Muiead A.K. Al-Fadhel

11. Al-Waqi'a. (1969). Iraqi newspaper No. 3625 in the year 13/2/1969. 